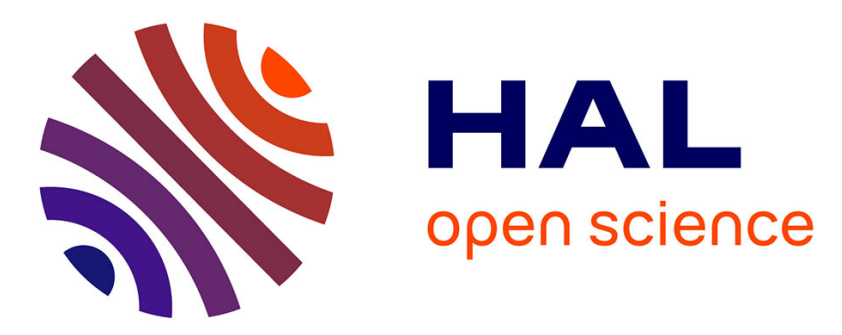

\title{
Range expansion and prey use of American mink in Argentinean Patagonia: dilemmas for conservation
}

Laura Fasola, Juan Muzio, Claudio Chehébar, Marcelo Cassini, David W.

Macdonald

\section{- To cite this version:}

Laura Fasola, Juan Muzio, Claudio Chehébar, Marcelo Cassini, David W. Macdonald. Range expansion and prey use of American mink in Argentinean Patagonia: dilemmas for conservation. European Journal of Wildlife Research, 2010, 57 (2), pp.283-294. 10.1007/s10344-010-0425-6 . hal-00620888

\section{HAL Id: hal-00620888 \\ https://hal.science/hal-00620888}

Submitted on 9 Sep 2011

HAL is a multi-disciplinary open access archive for the deposit and dissemination of scientific research documents, whether they are published or not. The documents may come from teaching and research institutions in France or abroad, or from public or private research centers.
L'archive ouverte pluridisciplinaire HAL, est destinée au dépôt et à la diffusion de documents scientifiques de niveau recherche, publiés ou non, émanant des établissements d'enseignement et de recherche français ou étrangers, des laboratoires publics ou privés. 


\title{
Range expansion and prey use of American mink in Argentinean Patagonia: dilemmas for conservation
}

\author{
Laura Fasola • Juan Muzio • Claudio Chehébar • \\ Marcelo Cassini • David W. Macdonald
}

Received: 28 March 2010/Revised: 12 August 2010/Accepted: 16 August 2010 /Published online: 9 September 2010

(C) Springer-Verlag 2010

\begin{abstract}
Following the establishment of American mink farms outside North America, the species has successfully invaded Europe and South America, and in some places, their presence demonstrably threatens native biodiversity. We surveyed for mink signs along the Andean Patagonian forest in Argentina from $38^{\circ} 52^{\prime} \mathrm{S}$ to $54^{\circ} 52^{\prime} \mathrm{S}$, revealing that their
\end{abstract}

Communicated by C. Gortázar

L. Fasola $\cdot$ D. W. Macdonald

Wildlife Conservation Research Unit, The Recanati-Kaplan

Centre, Zoology Department, University of Oxford,

Tubney House, Abingdon Road,

Tubney, Oxon OX13 5QL, UK

\section{J. Muzio}

Universidad Nacional del Comahue,

San Carlos de Bariloche, Río Negro,

Argentina

C. Chehébar

Delegación Regional Patagonia,

Administración de Parques Nacionales,

Vice Almirante O'Connor 1188 ,

8400 San Carlos de Bariloche, Río Negro,

Argentina

M. Cassini

Grupo de Estudios en Ecología de Mamíferos,

Departamento de Ciencias Básicas,

Universidad Nacional de Luján,

Rutas 5 y 7 ,

6700 Luján, Argentina

Present Address:

L. Fasola $(\bowtie)$

Laboratorio de Ecología y Conservación de Vida Silvestre,

Consejo Nacional de Investigaciones Científicas y Técnicas

(CONICET), Centro Austral de Investigaciones

Científicas (CADIC),

Bernardo Houssay 200 (V9410BFD),

Ushuaia, Tierra del Fuego, Argentina

e-mail: lalifasola@yahoo.com.ar range has now expanded to span $800 \mathrm{~km}$ of contiguous occupation on the continent including several types of wetlands and has also colonised Tierra del Fuego Island. Rate of expansion was estimated using two methodologies and varied between 5.53 and $9.00 \mathrm{~km} /$ year (linear method, largescale spread) and $4.86 \mathrm{~km} /$ year (within a more restricted area, grid method). Diet throughout the region fitted the generalist pattern described for mink elsewhere. Native small mammals were the most frequently consumed category. Crustaceans (patchily distributed in the region) occurred in the diet in proportion to their availability $\left(r_{\mathrm{s}}=0.961, p<0.001\right)$, but that of waterfowl did not $\left(r_{\mathrm{s}}=0.178, p=0.713\right)$. Diet was evaluated at one lake throughout a year, revealing that consumption of crustaceans fell in the cold months when bird abundance increased. Based on published work on the impact of American mink as an introduced species in Patagonia and elsewhere, together with our own survey, we discuss the implications of this invasion for biodiversity conservation in Argentinean Patagonia and the associated dilemmas for management policy.

Keywords American mink · Diet · Expansion rate Introduced species $\cdot$ Neovison vison $\cdot$ Patagonia

The natural geographic range of the American mink (Neovison vison) extends over much of North America and Canada (Dunstone 1993), across a diversity of ecosystems. Mink are typically associated with freshwater and coastal habitats where they hunt both in water and on land. This plasticity has made them successful invaders in Europe and South America, following escapes and releases from fur farms (Macdonald and Harrington 2003).

In South America, mink were introduced to Patagonia (Argentina and Chile) in the 1940s (Pagnoni et al. 1986; Jaksik et al. 2002) from fur farms. In Argentinean Patagonia, farms opened in Chubut and Tierra del Fuego 
Provinces (Pagnoni et al. 1986; Lizarralde and Escobar 2000; Jaksik et al. 2002; Fig. 1b) and some operated until the late 1970s. By the 1960s, feral populations were detected, as a consequence of escapes and releases from farms, (Foerster 1973; Chehébar et al. 1986; Massoia and Chebez 1993). A similar situation developed in Chile, following the closure of fur farms (Medina 1997; Jaksik et al. 2002). Once this range expansion became evident in Patagonia by the 1980s and 1990s, interest began to mount in the invasive status of American mink in Chile and Argentina (Jaksik et al. 2002; Anderson et al. 2006; Novillo and Ojeda 2008). Ecological studies also emerged, focused on (a) mink diet and habitat associations (Previtali et al. 1998), (b) mink ecology in the context of intra-guild interactions (Chehébar et al. 1986; Medina 1997; Aued et al. 2003; Delibes et al. 2003; Fasola et al. 2009) and (c) more recently studies on mink diet in relation to native and exotic prey (Ibarra et al. 2009; Schüttler et al. 2008), waterfowl vulnerability to mink predation (Schüttler et al. 2009) and waterfowl abundance fluctuations in relation to mink invading process (Peris et al. 2009). However, these studies were focused on restricted areas or areas of special interest (e.g. National Parks), and therefore, they have not provided a systematic overview of mink distribution and feeding habits across Patagonia. This is important since mink can have negative effects on native prey (birds: Craik 1997; Ferreras and Macdonald 1999; Clode and Macdonald 2002; Nordström et al. 2003, 2004; Nordström and Korpimäki 2004; small mammals: Barreto et al. 1998; Banks et al. 2008) or competitors (Maran et al. 1998; Sidorovich et al. 1999; Sidorovich and Polozov 2002) which may require management.

We conducted a large-scale survey of American mink distribution along the Andean Patagonian forest in Argentina. Based on previous literature and the present survey, we estimated rates of expansion for the species from two sources. We analysed mink diet across the study area, comparing freshwater habitats both within a locality and between seasons during a year and also between stages of colonisation.

\section{Methods}

\section{Study area}

The study area encompassed river basins or watersheds from latitude $38^{\circ} 52^{\prime} \mathrm{S}$ to $54^{\circ} 52^{\prime} \mathrm{S}$, along the Andean Patagonian forest in Argentina. The climate is cold temperate and humid; precipitation (ranging from 3,000 to $600 \mathrm{~mm}$ ) occurs mainly between June and September (cold months), often as snow (Cabrera 1971). The predominant habitat type is temperate forest, dominated by Nothofagus trees, mainly 'ñire' (Nothofagus antarctica) and 'lenga'
(Nothofagus pumilio) (Cabrera 1971). Recent glaciations shaped the hydrology of the region (Tatur et al. 2002) forming ultra-oligotrophic freshwater systems, low in productivity and in fish density and diversity (Pascual et al. 2007). Freshwater macro-crustaceans have a patchy distribution among watersheds (present in Limay, Hua Hum, Senguer and Corcovado-Pico River watersheds; Cassini et al. 2009). Beyond the core study area to the east stretches a semi-desert (steppe: annual precipitation below $600 \mathrm{~mm}$ ) characterized by shrubs, where lowland rivers are wider and slower flowing. In the Argentinean sector of Isla Grande de Tierra del Fuego, the main island of the Fuegian Archipelago (henceforth Tierra del Fuego), the forest occupies the southern half of the region and runs from west to east along the rocky coast of the Beagle channel.

\section{Mink survey}

From January to May 2005 and January to February 2006, we carried out mink surveys in freshwater systems in the following watersheds (in accordance to the Argentine Subsecretary of Hydrological Resources; www.hidricosargentina. gov.ar/MapaCuencas.html) from north to south: Limay, Hua Hum, Manso-Puelo, Futaleufú, Chubut (only three sites), Corcovado, Senguer, Buenos Aires, Santa Cruz, small Atlantic watersheds of Tierra del Fuego and Fagnano and along the southern coast of Tierra del Fuego (Fig. 1a). In total, we surveyed 447 sites, distributed over 68 lakes $(n=$ 350 sites), 62 rivers ( $n=85$ sites) and the coast ( $n=12$ sites). Most freshwater systems surveyed were located within the forest, but the Chubut, Limay and Senguer Rivers (Fig. 1b) were in the steppe ( $n=19$ sites). Six National Parks fall within these watersheds and were surveyed: Lanín NP, Nahuel Huapi NP, Lago Puelo NP, Los Alerces NP, Los Glaciares NP and Tierra del Fuego NP (Fig. 1a).

At each site (transect), we searched for American mink signs (footprints/scats) while walking $600 \mathrm{~m}$ (Bonesi and Macdonald 2004a) along riverbanks (one bank), lake shores or the coastline. Survey time at each transect ranged between 50 and $150 \mathrm{~min}$. Transects were separated by $4 \mathrm{~km}$ or more in freshwater systems. Positive sites were those in which we found at least one scat or footprint. At each site, we recorded the presence/absence of crustacean remains. We also counted the number of individuals and species of waterfowl seen in a 10 -min period at the end of each transect.

\section{Expansion rate}

Mink spread has been most thoroughly documented for northern continental Patagonia, where two main sources have been identified. Spread from these sources has now converged, and their relative dispersal before meeting is unknown. However, information is available on mink expansion 
Fig. 1 a Dark grey areas: watersheds visited with names to the right (Atlantic watersheds of Tierra del Fuego correspond to the Argentinean area of the Tierra del Fuego outside Fagnano Lake watershed). National Parks that were visited are indicated as black areas with names in italics on the left. $\mathbf{b}$ White squares: original location of mink farms considered main sources of invasion. Names in italics: Patagonian provinces (southern Argentina). Grey dots: location of transects where we checked for mink signs. Black points: transects containing American mink signs. Black open circles indicate the sites of the three steppe rivers visited (names on the right)
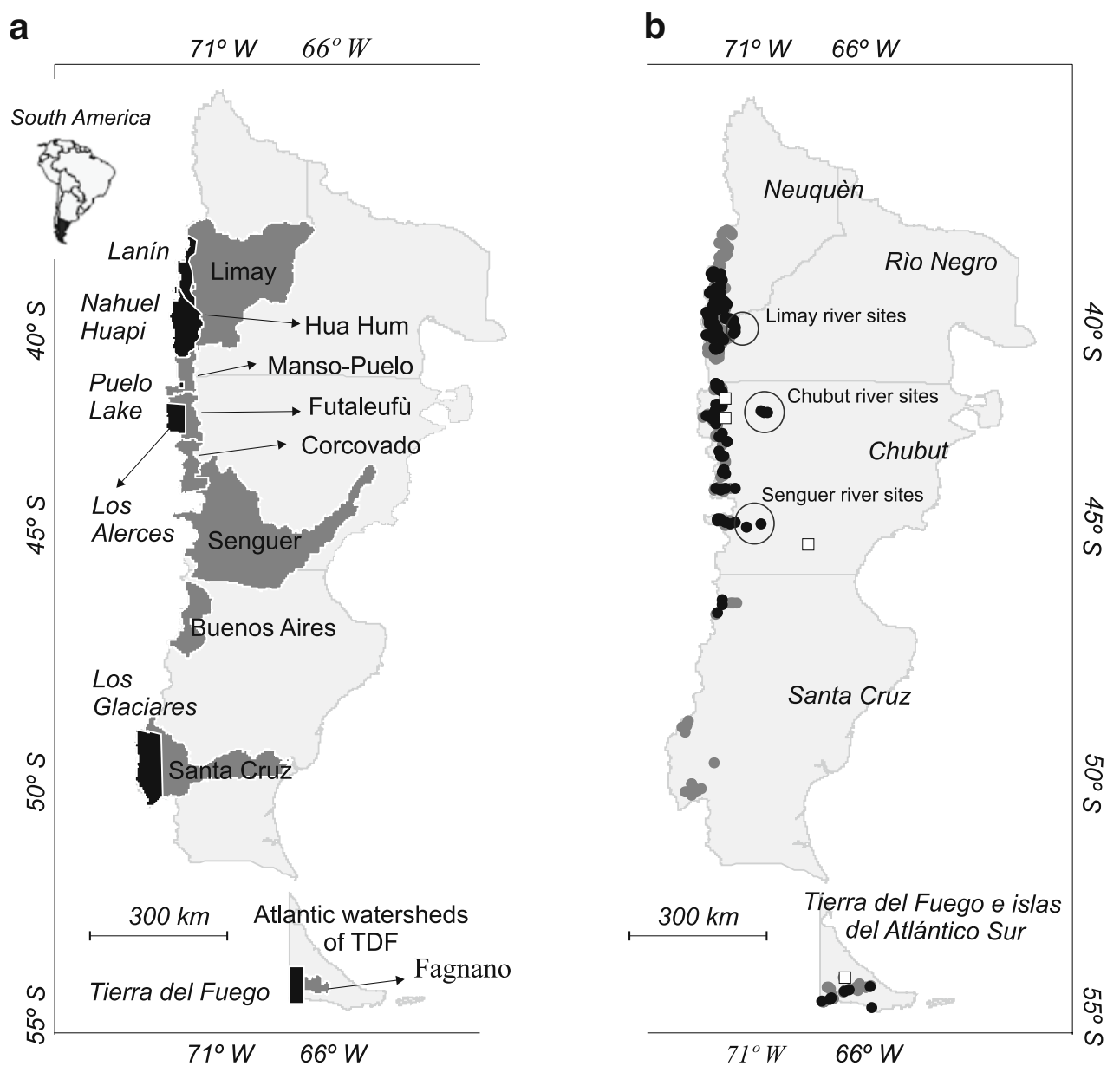

northward and southward from the northern (NS) and southern (SS) sources, respectively (Fig. 2). The NS corresponds to a group of three fur farms that were opened in the area, not simultaneously, between 1946 and 1971 (localities of Cholila and Futalaufquen Lake; Pagnoni et al. 1986) and is thought to be the origin of the mink population that invaded Nahuel Huapi National Park (Figs. 1a and 2). Documentation of this advance was recorded by Chehébar (1985), Chehébar et al. (1986) and Chehébar and Porro (1998). Additional information of mink spread in Nahuel Huapi National Park comes from the location of mink scat samples collected in 1988. We discarded information of expanding mink for Nahuel Huapi National Park after 1995, because a second current invasion from Chile (west) is thought to have entered the area after that time (Peris et al. 2009). Mink expanding south into Santa Cruz Province had a single origin in central Chubut, where one farm operated between 1956 and 1975 (locality of Sarmiento; Fig. 2). Assuming that feral animals had established by 1960 (time 0, $\left[t_{0}\right]$; Chehébar et al. 1986), we computed 'straight line estimations'. For spread of the SP: from its source at Sarmiento locality $\left[t_{0}\right]$ to Jeinimeni River in Santa Cruz Province $\left[t_{1}\right]$. We made three estimates of the spread of the NP: first, from source point $\left[t_{0}{ }^{\prime}\right]$ to Fonk Lake $\left[t_{1}{ }^{\prime}\right]$ (the northern limit reported for 1982 in Chehébar 1985), second estimate from Fonk Lake $\left[t_{1}{ }^{\prime}\right]$ to Limay River $\left[t_{2}{ }^{\prime}\right]$ (La Lipela; northern collection site of scats in 1988) and the third estimate from Limay River $\left[t_{2}{ }^{\prime}\right]$ to Villarino-Falkner lakes $\left[t_{3}{ }^{\prime}\right]$ (northern limit reported for 1995 Chehébar and Porro 1998; Fig. 2). These data are sufficient to allow only coarse linear measurements of distance from the points of origin. For SS (southward flow), the distance (in longitude) between points is greater than $200 \mathrm{~km}$, so we used the diagonal as the straight line showing mink advance. For spread from NS, all points fall within a fringe of $55 \mathrm{~km}$; thus, all advance paths considered for calculations were straight lines joining the different latitudinal edges of mink advance.

There is only one previous estimate of the rate of the mink's range expansion in Argentinean Patagonia (Pagnoni et al. 1986); this assumed different expansion routes along rivers and dates of arrival at different points were obtained through postal questionnaires to local inhabitants. Estimates were 7.7 and $5.5 \mathrm{~km}$ /year along waterlines/rivers crossing steppe habitat and forest habitat, respectively.

Also for comparison with the literature, we used information on mink distribution in a more restricted area within Nahuel Huapi National Park (Chehébar 1985; Chehébar and Porro 1998). To estimate the expansion rate as described in Ruiz- 
Fig. 2 Expansion directions (grey arrows) from original releasing points: mink farms indicated with filled squares and the name of the locality. Provinces names inside rectangles. SS southern source nearby the locality of Sarmiento, $N S$ northern source between the locality of Cholila and Futalaufquen Lake nearby Los Alerces National Park (italics, grey shaded). From NS ( $\left.t_{0}{ }^{\prime}\right)$ to a Fonk Lake $\left(1983 ; t_{1}\right)$, to b La Lipela $\left(t_{2}{ }^{\prime}\right)$ and to $\mathbf{c}$ VillarinoFalkner lakes $\left(1995 ; t_{3}\right)$ within Nahuel Huapi National Park (italics, grey shaded). From SS $\left(t_{0}\right)$ to c Jeinimeni River $\left(2005 ; t_{1}\right)$ in Santa Cruz Province

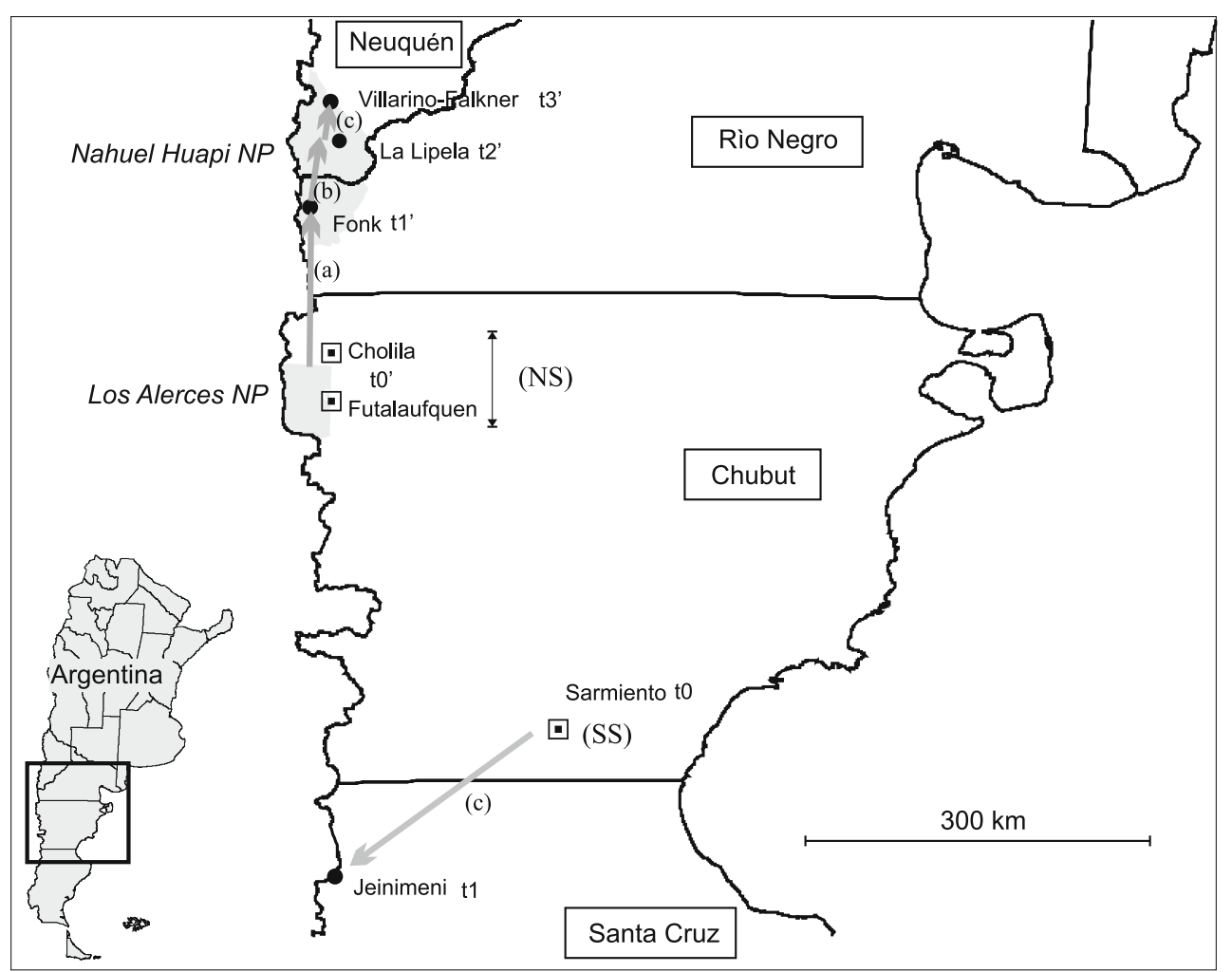

Olmo et al. (1997), where the rate of expansion (TE) equals the square root of the area gained (measured in a grid as newly occupied $10 \times 10 \mathrm{~km}^{2}$ cells) divided by the interval between surveys (expressed in years). Formula (Ruiz-Olmo et al. 1997): TE $=(S)^{1 / 2} \times 1 / t$, where $S$ is the area incremented in the period of time considered $t$.

\section{Scat collection}

Scats found at survey sites were collected for diet analysis (below) in Limay, Hua hum, Manso-Puelo, Futaleufú, Corcovado-Pico, Senguer, Buenos Aires and the coast. Additionally, from February to December 2005, three sections $(5,2$ and $3 \mathrm{~km}$, separated by at least $4 \mathrm{~km})$ along the shore of Moreno Lake (perimeter $34 \mathrm{~km}$, area $12 \mathrm{~km}^{2}$ ) in the vicinity of Nahuel Huapi National Park were surveyed monthly for scat collection.

During the 1980s, one of us (C. Chehébar) and other personnel of the National Parks Administration collected scat samples from the Limay watershed (Limay River and Nahuel Huapi Lake) and Futaleufú watershed (within Los Alerces National Park; Fig. 1). These data served as a baseline for comparison between different colonisation stages (1980s: earlier colonisation stage; 2000s: later colonisation stage) in two watersheds with different availability of prey (only the Limay watershed has freshwater crustaceans, Cassini et al. 2009).
Scat analysis

Scats were soaked in warm water to facilitate separation of prey remains. Undigested prey remains were sorted into four categories: birds (feathers, bone fragments), mammals (hair, teeth and bone fragments), crustaceans (exo-skeleton fragments) and fish (mainly vertebrae and scales). Mammalian teeth and the medullar and cuticle scale patterns of hair were compared to identification guides or animal collections (Chehébar and Martín 1989; Pearson 1995) to identify genera and species when possible. For freshwater fish species, vertebrae were used to discriminate between native genera (mainly Percichthys and Galaxias) and exotic salmonids (mainly Salmo trutta, Salvelinus fontinalis and Oncorhynchus mykiss). For marine fish species, we identified remains to genus following Gosztonyi and Kuba (1996). For each scat, we recorded (a) items present and (b) their percentage in the scat total volume.

We used scat results grouped by watersheds to compute three different indices: the relative frequency of occurrence of prey items (RFO; Bonesi et al. 2004), the percentage of occurrence of the dominant item (PDO; Schüttler et al. 2008) and mean percentage of scat volume (PV). RFO was calculated as the number of occurrences of a prey class divided by the total number of occurrences of all prey classes multiplied by 100 . PDO was calculated as the number of occurrences of the dominant item, divided by the number of 
samples multiplied by 100 . PV accounts for the mean volume of the item in scats grouped by watershed. Every index has benefits and disadvantages. RFO overestimates the representation of secondary items (e.g. some insects) but maintains those items that are highly digested (e.g. fish, molluscs). PDO solves the problem of secondary prey items but underestimates those items highly digested. PV seems to reflect better what is found in scats. We compared the relative behaviour of the three indexes through correlation analysis (Spearman's rank correlations, excluding ties).

For analysis, we grouped results to test variations in mink diet (a) among watersheds, (b) between habitats (lakes, rivers and coastal samples were excluded) with and without crustaceans (since the distribution of freshwater crustaceans is heterogeneous along the study region Cassini et al. 2009), (c) among seasons (for Moreno Lake: summer, autumn and winter) and (d) between an earlier colonisation stage (1980s) and the present colonisation situation (2005) for two watersheds (Limay and Futaleufú and Manso). We employed chi-squared tests to evaluate these variations and Fisher's exact test for count data when $20 \%$ or more of the expected frequencies were below 5 (Zar 1984). Mammals, fish and birds were used for all the comparisons. Crustaceans were included only in comparisons when all data sets involved crustaceans. Reptiles and insects were excluded from analyses. The former group was removed due to low numbers across watersheds. Insects were excluded in order to avoid confusion with secondary prey, as some of the native Patagonian rodents that are prey to mink are insectivorous (Pearson 1995).

To test the relationship between consumption and the proportion of transects where a prey type were sighted (crustaceans/waterfowls) amongst watersheds, we calculated Spearman's rank correlation coefficient. Statistical analyses were conducted in $\mathrm{R}$ version 2.9.1 ( $\mathrm{R}$ Development Core Team 2009), and statistical significance was accepted at $p<$ 0.05. Bonferroni correction to $\alpha$ was computed when multiple comparisons were conducted $\left(\alpha\right.$ corrected $=\alpha / n^{\circ}$ of comparisons).

\section{Results}

\section{Distribution}

Mink signs were present in ten of 11 watersheds surveyed: Limay, Hua Hum, Manso-Puelo, Futaleufú, Chubut, Corcovado-Pico, Senguer, Buenos Aires, Fagnano and the Atlantic watersheds of Tierra del Fuego but were not found in Santa Cruz watershed. Mink scats were also found along the coast of the Beagle Channel (Fig. 1b). Of our survey, 386 of 447 sites were within the limits of the area found to be occupied by mink, and 188 (49\%) of these sites were positive for mink signs. Scats were found in 165 sites, and within this group, footprints were also detected at seven sites. Footprints were found exclusively at 23 sites. All sites where footprints were detected had sand or mud as substrate.

Since 1960s (when the first feral individuals were sighted), mink have expanded such that we found them at sites encompassing an area of $72,900 \mathrm{~km}^{2}$ of western continental Argentinean Patagonia $\left(360,000 \mathrm{~km}^{2}\right)$ or $23,000 \mathrm{~km}^{2}$ considering only sites within the forest (approximately $70,000 \mathrm{~km}^{2}$ ). Mink signs in Tierra del Fuego (total Argentinean area, approximately $20,210 \mathrm{~km}^{2}$ ) were found over an area of $3,050 \mathrm{~km}^{2}$. The presence of mink on the mainland was continuous from the southwest of Neuquén Province to the northwest of Santa Cruz (Fig. 1b) where they occupied most freshwater systems. In Tierra del Fuego, only the southern half of the Argentinean portion of the island was surveyed, where mink occurred in several types of aquatic systems (lakes, rivers and the coast).

\section{Rate of expansion}

Rate of expansion ('straight line estimation') southwards was $5.53 \mathrm{~km} /$ year (249 linear $\mathrm{km}$ in 45 years). Northwards expansion rates were $6.9 \mathrm{~km} /$ year (152 linear $\mathrm{km}$ in 22 years), $9 \mathrm{~km} /$ year (54 linear km in 6 years) and $6 \mathrm{~km} /$ year (42 linear $\mathrm{km}$ in 7 years; average $7.3 \mathrm{~km} /$ year). Spread involved crossing several watershed divides. For northward spread, the mink crossed above two divides (from Futaleufú watershed into Manso and finally crossed into Limay watershed) including crossings of several divides between different lake systems within main watersheds. Southward flow also involved crossing two watershed divides (from Senguer into Deseado and then into Buenos Aires watershed). Expansion rate in accordance to the Ruiz-Olmo et al. (1997) methodology for Nahuel Huapi National Park between 1983 and 1995 resulted in $4.86 \mathrm{~km} /$ year (Fig. 3).

\section{Diet}

We analysed 390 scats in total. Mink diet in freshwater systems included mammals, crustaceans, fish and birds. Crustaceans were consumed in all watersheds where they occurred (Cassini et al. 2009). Along the coast, we found that mammals, fish and birds were preyed upon by mink, though there were few scats and therefore we excluded them from all the subsequent analyses.

The indices calculated for each watershed by prey item are shown in Table 1. The correlations among the indices across watersheds were all positive and highly significant: RFO vs PDO $r_{\mathrm{s}}=0.919, p<0.001, n=24$; RFO vs PV $r_{\mathrm{s}}=$ 0.957, $p<0.001, n=27$ and PDO vs PV $r_{\mathrm{s}}=0.961, p<0.001$, $n=27$ (we therefore used the RFO index to display the results). 
Fig. 3 Nahuel Huapi National Park. Grid: $10 \times 10 \mathrm{~km}^{2}$. 1983: grey ovals show squares where mink presence was detected (Chehébar 1985). 1995: grey dotted ovals indicate squares occupied in 1983 and dark grey ovals show colonised squares between 1983 and 1995 (Chehébar and Porro 1998)

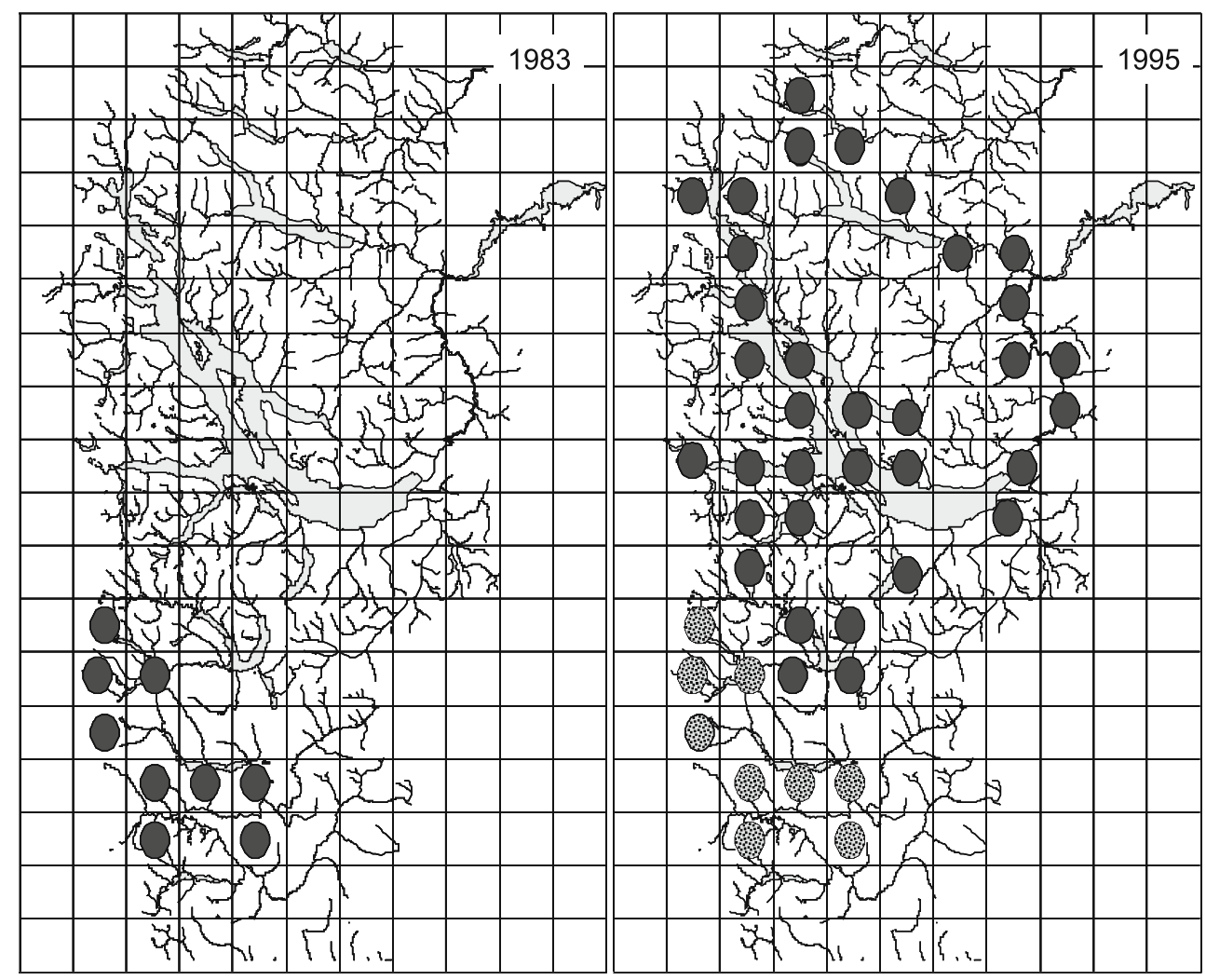

Mammals were the most consumed dietary item in all watersheds but one, the Hua Hum watershed where crustaceans were the most consumed prey group. Bird and fish consumption levels were always lower than those of mammals in freshwater systems. Proportion of fish in scats was higher in the watersheds located to the south. Crustaceans' representation in diet was highly variable. On the coast, mammals and fish appeared to be eaten equally (Table 1).

Native mammals were consumed more than introduced ones (Table 2). Exotic fish were more consumed than native fish (Table 2). Incidental identification of bird remains included Georgian Teal (Anas georgica), Black-necked Swan (Cygnus melanoryphus) and Upland Goose (Chloephaga picta). Coastal scats contained remains of marine fish (mainly Patagonotothen sp.).

Consumption of prey types other than crustaceans (absent from some of the watersheds) did not differ across watersheds $\left(\chi^{2}=18.23, p=0.196, d_{\text {. } f .}=14\right.$; pooled data are displayed in Fig. $4 \mathrm{a}$ to show the general pattern). Diet was also similar between habitat types (between lakes and rivers within watersheds with crustaceans: $\chi^{2}=0.57, p=0.903, d_{.} .=3$; between lakes and rivers within watersheds without crustacean: $\chi^{2}=0.03, p=0.985, d_{\text {. }} .=2$ ).

The frequency of occurrence of crustaceans in mink scats (grouped by watershed) was positively correlated with the proportion of transects (per watershed) in which crustacean remains were found $\left(n=7, r_{\mathrm{s}}=0.961, p<0.001\right.$; Fig. 5a). Neither the proportion of transects in each watershed where waterfowls were sighted nor the total number of waterfowls by the total number of transects were significantly correlated with the frequency of occurrence of birds in mink scats $(n=7$, $r_{\mathrm{s}}=0.378, p=0.407$ (Fig. 5b) and $r_{\mathrm{s}}=0.178, p=0.713$ respectively). Summer diet did not differ between the 1980s (earlier spread) and 2005 for the Futaleufú watershed (without crustaceans, $\chi^{2}=3.59, p=0.166, d . f .=2$ ) or for the Limay watershed (with crustaceans, Fisher's exact test: $p=0.220$ ).

Prey occurrence at Moreno Lake (in Nahuel Huapi Lake area, within Limay watershed) varied among seasons (Fig. 4b; summer-autumn-winter: Fisher's exact test: $p=0.0091$ ) due to differences among autumn and winter (Bonferroni corrected $\alpha$ 0.016; Fisher's exact test: summer-autumn, $p=0.421$; summer-winter, $p=0.026$ and autumn-winter: $p=0.004$; excluding fish due to low numbers). Consumption of crustaceans and birds varied the most: consumption of birds peaked during winter when the consumption of crustaceans was the lowest.

\section{Discussion}

Agreement of results with other studies

We found that American mink in Argentinean Patagonia are distributed continuously along water systems from Neuquén Province (between Paimún-Huechulafquen and Tromen lakes) 


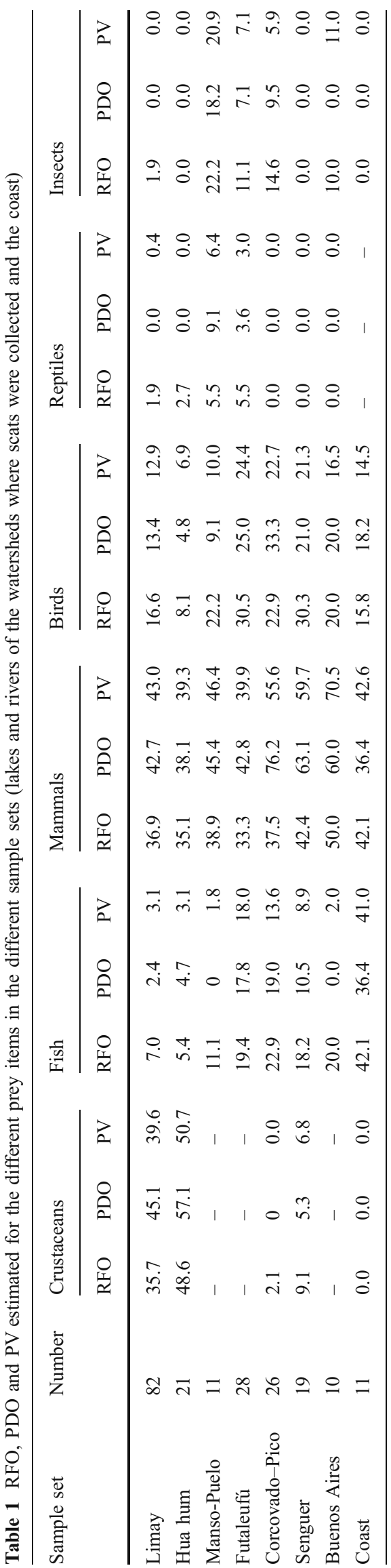

Table 2 Occurrences of the different prey encounter in American mink scats

\begin{tabular}{|c|c|}
\hline Prey & Occurrence \\
\hline Mammals & 132 \\
\hline \multicolumn{2}{|l|}{ Family: Cricetidae } \\
\hline Abrothrix & 5 \\
\hline Loxodontomys & 11 \\
\hline Chelemys & 21 \\
\hline Phyllotys & 1 \\
\hline Irenomys & 5 \\
\hline Reithrodon & 4 \\
\hline \multicolumn{2}{|l|}{ Family: Muridae } \\
\hline Rattus & 2 \\
\hline Family: Leporidae $^{\mathrm{a}}$ & 23 \\
\hline \multicolumn{2}{|c|}{ Family: Microbiotheridae } \\
\hline Dromiciops & 1 \\
\hline Unidentified & 63 \\
\hline Birds & 73 \\
\hline Unidentified & 73 \\
\hline Freshwater fish & 37 \\
\hline Native $^{b}$ & 9 \\
\hline Exotic & 16 \\
\hline Unidentified & 12 \\
\hline Freshwater crustaceans & 78 \\
\hline Aegla & 62 \\
\hline Sammastacus & 24 \\
\hline Reptiles & 6 \\
\hline Insects & 20 \\
\hline
\end{tabular}

${ }^{\mathrm{a}}$ Lepus capensis or Oryctolagus cuniculus

${ }^{\mathrm{b}}$ Percichthys

to the southern Province of Santa Cruz (Buenos AiresPueyrredón Lake; approximately $800 \mathrm{~km}$ north-south along the Andes) and that they are present in several locations of the southern half of the Argentinean portion of Tierra del Fuego (including freshwater systems and the Beagle Channel coast).

The mink's Northward spread has been faster than its spread to the south. The three estimates made here (ranging from 5.53 to $9 \mathrm{~km} /$ year) are comparable to the only two previous values available for the southern hemisphere, when Pagnoni et al. (1986) considered the spread of mink prior to 1986 in Chubut Province, Argentina. If these rates of expansion continue (average $7.3 \mathrm{~km} / \mathrm{year}$ ), the northern limit of Lanin National Park ( $80 \mathrm{~km}$ north to the front of mink expansion Fig. 1b) could be reached by 2016, with the consequence that the national park would then be completely colonised. Our data for the spread within Nahuel Huapi National Park fell within the range reported in Spain, where American mink are also invasive (TE: from 1.5 to 10; Ruiz-Olmo et al. 1997). 

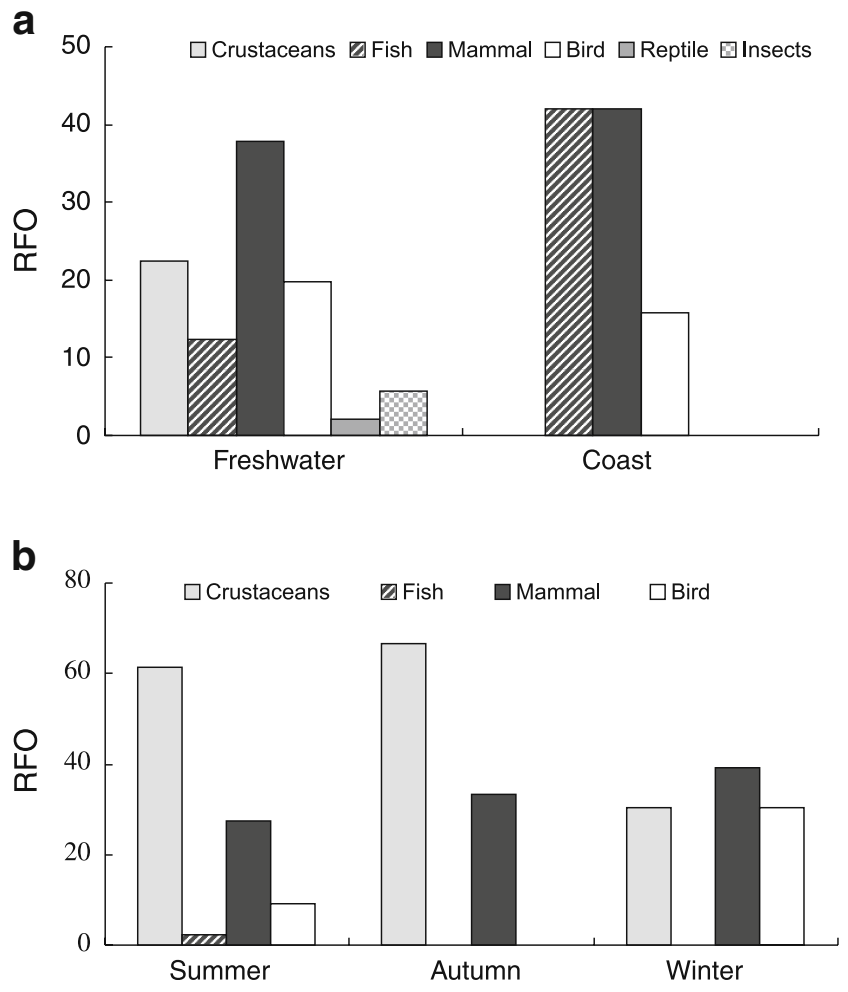

Fig. 4 Relative frequency of occurrence of different prey class (occurrences/total occurrences $\times 100$ ) found in scats collected (a) in summer 2005/2006 Patagonian freshwater systems of seven different watersheds $(N=197)$ and on the coast $(N=11)$ and $\mathbf{b}$ in Moreno Lake within Limay watershed along 2005 in summer $(N=29)$, autumn $(N=$ $17)$ and winter $(N=16)$

Mammals, particularly cricetid native rodents, were the principal prey found in mink scats collected along the freshwater systems of western Patagonia. Other important prey categories were crustaceans (when available) and birds. In contrast to findings elsewhere (e.g. Erlinge 1969; Melquist et al. 1981, Table 3; Dunstone 1993; Bonesi et al. 2004), fish consumption was low, possibly reflecting the low abundance and paucity of species of freshwater fish in Patagonia (Pascual et al. 2007). Diet in watersheds where crustaceans are available was similar to that previously reported for mink in freshwater systems of Patagonia (Medina 1997; Previtali et al. 1998; Table 3). However, our study extended beyond the crustaceans' distribution (see also the results of Ibarra et al. (2009) from Navarino Island, another area without crustaceans, but with which comparisons are confounded by the high availability of ground-nesting birds naïve to mammalian predators).

We found that coastal mink on Tierra del Fuego ate mammals and fish at similar frequencies, whereas Schüttler et al. (2008) reported that mink on the north coast of Navarino Island (south of the Beagle Channel), consumed prey in descending order from mammals, birds, fish and crustaceans (Table 3). These differences could fruitfully be explored by systematic study of larger samples, in relation to prey availability, on both sides of the Beagle Channel.

Most consumed mammals were native species while invasive murid rodents and lagomorphs were less represented in the diet. We suggest that this is largely explained by the habitat preferences of invasive species. Murid rodents in Patagonia are always associated with human habitations (Pearson, 1995), and since this region is characterized by very low human densities, the low representation of invasive murid rodents in mink scats was expected. In the case of lagomorphs and specially hares which are more broadly distributed in Patagonia, they are abundant in almost all habitats excepting dense forest (Pearson, 1995). The fact that a high proportion of our transects were in the forest therefore has bearing on the low representation of hares in the mink's diet. Additionally, hares do not build den holes as rabbits do, so they may be more difficult to catch for mink. The opposite result emerged for fish prey, where exotic fish species were disproportionately important in mink diet. Patagonian freshwater systems have low productivity and low fish density and diversity (Pascual et al., 2007), and
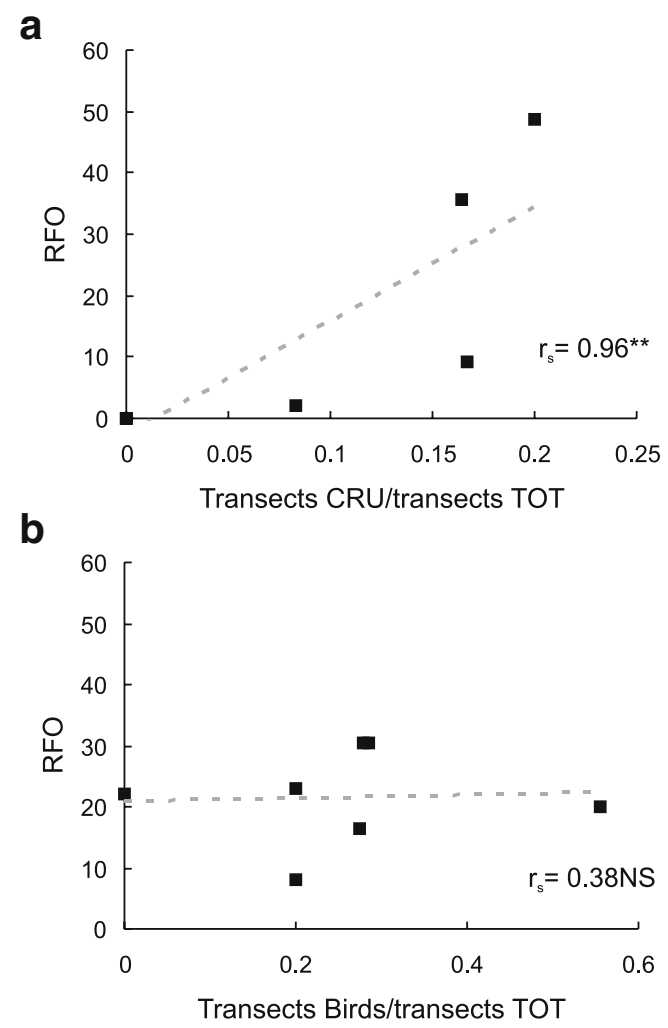

Fig. 5 a Relative frequency of occurrence of crustaceans vs the proportion of transects with crustaceans remains in each watershed $(N=$ 7). b Relative frequency of occurrence of birds in mink diet vs the proportion of transects with bird sightings visited in each watershed $(N=7)$. Regression line as a dotted line; $* *$ indicates $p<0.05$, NS indicates $p>0.05$ 
Table 3 RFO (prey absolute frequency/all occurrences $\times 100$ ) reported in studies conducted in South America and one for mink native range

Cru crustaceans, Mam mammals, Bir birds, Rep reptiles, Inse insects, $\mathrm{Mol}$ molluscs, $\mathrm{FW}$ freshwater, $S C$ seacoast

${ }^{a}$ Native range

\begin{tabular}{|c|c|c|c|c|c|c|c|c|c|}
\hline Reference & & Place & $\mathrm{Cru}$ & Fish & Mam & Bir & Rep & Inse & Mol \\
\hline Melquist et al. (1981) & FW & USA & 0.0 & 40.0 & 29.0 & 13.0 & 1.0 & 16.0 & - \\
\hline Previtali et al. (1998) & FW & Argentina & 36.0 & 13.4 & 15.2 & 11.0 & 1.2 & 23.2 & 0.0 \\
\hline Medina (1997) & FW & Chile & 47.4 & 8.3 & 40.4 & 2.6 & 0.0 & 1.3 & 0.0 \\
\hline Schüttler et al. (2008) & $\mathrm{SC}$ & Chile & 10.9 & 15.5 & 29.2 & 30.7 & - & 10.7 & 3.0 \\
\hline Ibarra et al. (2009) & FW & Chile & 1.9 & 2.7 & 39.9 & 37.7 & - & 17.7 & 0.0 \\
\hline \multirow[t]{2}{*}{ Present work } & FW & Argentina & 22.3 & 12.32 & 37.8 & 19.8 & 2.0 & 5.7 & 0.0 \\
\hline & $\mathrm{SC}$ & Argentina & 0.0 & 42.1 & 42.1 & 15.8 & - & 0.0 & 0.0 \\
\hline
\end{tabular}

First, $20 \%$ of all the occurrences in faeces were of bird remains (this figure rising above $30 \%$ in watersheds without crustaceans). This is higher than generally reported (USA: Melquist et al. 1981; Canada: Racey and Euler 1983; Estonia: Maran et al. 1998; Poland: Jêdrzejewska et al. 2001; England: Bonesi et al. 2004; Spain: Melero et al. 2008). There are places where a negative effect of American mink on the breeding success of bird populations has been demonstrated (Craik 1997; Ferreras and Macdonald 1999 [with only $23 \%$ of waterfowl RFO in diet]; Nordström et al. 2004; Clode and Macdonald 2002). On Navarino Island, Schüttler et al. (2009) reported evidence of mink predation damaging the reproductive success of some solitary-nesting waterfowl species. In Argentina, Foerster (1973) reported decreasing trends for 15 waterfowl species and one mammal species, coypu (Myocastor coipu), in Los Alerces National Park in the vicinity of one of the original source populations of invading mink (NS, Fig. 2). Also in Argentina, Peris et al. (2009) studied the relationship between waterfowl abundances in lakes of Lanín National Park and the presence of mink (at the edge of their distribution) and found it to be negative for 12 species. However, as they are correlational results, they must be treated with caution. So, although there are clearly grounds to be apprehensive about the impact of American mink on native biodiversity in Patagonia, evidence for negative impacts is sparse.

Second, crustaceans are the main prey for the native southern river otter Lontra provocax (Chehébar 1985; Aued et al. 2003) and are a key factor determining otter distribution in freshwater systems (Cassini et al. 2009). Moreover, Fasola et al. (2009) suggested that the coexistence of river otter and mink is facilitated by the abundance of crustaceans. However, whereas inter-specific competition is apparent within some mustelid guilds (Dayan and Simberloff 1994) and specifically American mink are inimical to European mink (Sidorovich et al. 1999), the general finding is that otters displace mink (Bonesi and Macdonald 2004b; Bonesi et al. 2004) or may cause them to change their behaviour (Harrington et al. 2009b). There is no evidence that American mink compete with southern river otters $L$. provocax, and against this background, it seems unlikely that they would. The intricacies of their inter-specific 
interactions nonetheless merit further study. Similarly, the interactions on Tierra del Fuego between mink-as a new entrant to the coastal carnivore guild - and the southern river otter, sea otter Lontra felina, as well as interactions with Culpeo fox Pseudalopex culpaeus and grey fox Pseudalopex griseus, all remain unknown.

Third, our study reports current mink distribution throughout much of the forested portion of western Patagonia. One of the main sources of mink was in the centre of Chubut Province (Fig. 1), from which mink may have expanded northeastwards along the Chico River to the Chubut River (Atlantic drainage). We confirmed the presence of mink in the upper Chubut River, but the eastern front of their spread has not been fully documented (lower Chubut River) and, from its mouth, along the Atlantic coast. At least eight species of sea birds breed on the Atlantic coast of Chubut Province (Yorio et al. 1998), where some colonies are decreasing (e.g. Magellanic penguin Spheniscus magellanicus), due to commercial fisheries and oil spills (Schiavini et al. 2005). The possible future expansion of mink towards the east in Patagonia surely merits precautionary vigilance.

In the same vein, we recorded mink signs in the southern part of Tierra del Fuego (in agreement with Lizarralde and Escobar 2000), along the coast (Beagle Channel) that is permanent habitat and breeding grounds for seabird and waterfowl species (Schiavini and Yorio 1995; Raya Rey and Schiavini 2000) including the species described as vulnerable to mink predation in Schüttler et al. (2009) work along the northern coast of Navarino Island. The importance and possible susceptibility of these bird populations again raises precautionary anxiety about mink impact. The same anxiety concerns the likelihood of their colonisation of other islands of the Fuegian Archipelago currently free of terrestrial carnivores. Mink have already crossed the Beagle Channel from Tierra del Fuego to parts of the Cape Horn Biosphere Reserve, specifically Hoste Island (Anderson et al. 2006) and Navarino Island (Rozzi and Sherrifs 2003), where their summer diet is heavily dependent on native birds (Schüttler et al. 2008; Ibarra et al. 2009).

\section{Management issues}

The impact of any invasive non-native species is likely to depend on its life history characteristics and those of its prey and competitors and also on the numbers and circumstances of its introduction. These characteristics and the resulting pattern of density dependence affecting the mortality of the prey are likely to differ between introduced species and within species under different circumstances (see Macdonald et al. 2007). Therefore, in the absence of evidence for negative invasive effects of mink in Patagonia, it is difficult to form a robust opinion on the need for their control, or the scale at which it should be considered. At the least, experience with the damaging aspects of mink invasions in the Northern Hemisphere demands precautionary vigilance. On the other hand and in the absence of irrefutable evidence of damage to native biodiversity, killing mink in order to systematically eradicate them from Patagonia would be very challenging, extremely expensive and raises ethical issues. Our data provide the first comprehensive information of current mink distribution in Patagonia and provide a foundation for scientific consideration of the need for local or widespread mink control. That consideration can benefit from parallel research in Europe, for example, on modelling the control of mink (Bonesi et al. 2007), experimental test of its efficacy (Harrington et al. 2009a), aspects of scale and the factors associated with success elsewhere (Bonesi and Palazón 2007). Case studies are also revealing: for example, Banks et al. (2008) reported the positive effect of mink removal for Finish island vertebrates' recovery. Inevitably, conservation interventions often have to be planned in the absence of complete information, requiring difficult judgments that can be assisted by risk analyses (Lodge and ShraderFrechette 2003). Although science lays the foundations for such decisions, policy is ultimately based on judgment.

While we have provided comprehensive information on the spread of mink in Patagonia, data on the impact of these mink are inadequate to provide confidence in deciding upon the need for their control. We might be impressed by the absence of evidence of a serious damage on native species, but in the light of international experience, we are not sufficiently confident to assume that this constitutes evidence of absence of such damage.

Against this background, what information would improve the scientific evidence on which control policy for the region might be based? We suggest that priorities include (a) detailed study of the impact of mink and other predators on waterfowl and seabirds nesting on either side of the Beagle Channel, (b) systematic study of the impact of the arrival of mink at the front of their current spread in continental Patagonia (Neuquén and Santa Cruz provinces), (c) quantitative assessments of any effect of mink predation on particular prey populations (e.g. the macro-crustaceans that are the main energetic source for freshwater populations of southern river otters and also prey for American mink and introduced salmonids) and (d) regional surveys on the eastern edge of mink spread in Patagonia.

Acknowledgements Gerardo Porro trained fieldworkers for signs identification and conduct fieldwork within Nahuel Huapi National Park. Marcelo Bello and Leonardo R. Leggieri collaborated during the fieldwork. Sandra Almada Chavez, Adriana Gallur, María Gottelli and Patricia Livingston collaborated with diet identification. Leonardo Di Franco supervised the GIS analysis, and PRODITEL provided the GIS software. Victor Cussac was the Co-supervisor of the Undergraduate Thesis of Juan Muzio. We thank Lauren Harrington, Christopher B. Anderson and Alejandro E. J. Valenzuela for advice and helpful comments on previous versions. The study was financed by the Darwin Initiative (UK). 


\section{References}

Anderson CB, Rozzi R, Torres-Mura JC, McGehee SM, Sherriffs MF, Schütler E, Rosemond AD (2006) Exotic vertebrae fauna in the remote and printine sub-Antarctic Cape Horn Archipelago, Chile. Biodivers Conserv 15:3295-3313

Aued MB, Chéhebar C, Porro G, Macdonald DW, Cassini MH (2003) Environmental correlates of distribution of southern river otters (Lontra provocax) at different ecological scales. Oryx 37:413-421

Banks P, Nordström M, Ahola M, Salo P, Fey R, Korpimäki E (2008) Impacts of alien mink predation on island vertebrate communities of the Baltic Sea Archipelago: review of a long term experimental study. Boreal Environ Res 13:3-16

Barreto GR, Rushton SP, Stratchan R, Macdonald DW (1998) The role of habitat and mink predation in determining the status and distribution of water voles in England. Anim Conserv 1:129-137

Bonesi L, Macdonald DW (2004a) Evaluation of sign surveys as a way to estimate the relative abundance of American mink (Mustela vison). J Zool (Lond) 262:65-72

Bonesi L, Macdonald DW (2004b) Impact of released Eurasian otters on a population of American mink: a test using a experimental approach. Oikos 106:9-18

Bonesi L, Palazón S (2007) The American mink in Europe: status, impacts and control. Biol Conserv 134:470-483

Bonesi L, Chanin P, Macdonald DW (2004) Competition between Eurasian otter Lutra lutra and American mink Mustela vison probed by niche shift. Oikos 106:19-26

Bonesi L, Rushton SP, Macdonald DW (2007) Trapping for mink control and water vole survival: identifying key criteria using a spatially explicit individual based model. Biol Conserv 136:636-650

Cabrera AL (1971) Fitogeografía de la República Argentina. Bol Soc Argent Botánica 14:1-42

Cassini MH, Fasola L, Chehébar C, Macdonald DW (2009) Scaledependent analysis of an otter-crustacean system in Argentinean Patagonia. Naturwissenschaften 96:593-599

Chehébar C (1985) A survey of the southern river otter Lutra provocax Thomas in Nahuel Huapi National Park, Argentina. Biol Conserv 32:299-307

Chehébar C, Martín S (1989) Guía para el reconocimiento microscópico de los pelos de los mamíferos de Patagonia. Doñana Acta Vertebr 16:247-291

Chehébar C, Porro G (1998) Distribución y estatus del Huillín (Lutra provocax) en el Parque Nacional Nahuel Huapi, Argentina. Vida Silv Neotrop 7:99-106

Chehébar C, Gallur A, Giannico G, Gottelli M, Yorio P (1986) A survey of the southern river otter Lutra provocax in Lanín Puelo and Los Alerces National Parks, Argentina and evaluation of its conservation status. Biol Conserv 38:293-304

Clode D, Macdonald DW (2002) Invasive predators and the conservation of island birds: the case of American mink Mustela vison and terns Sterna spp. in the Western Isles, Scotland. Bird Study 49:118-123

Craik JCA (1997) Long term effects of North American mink Mustela vison on seabirds in western Scotland. Bird Study 44:303-309

Dayan T, Simberloff D (1994) Character displacement, sexual dimorphism and morphological variation among British and Irish mustelids. Ecology 75:1063-1073

Delibes M, Travaini A, Zapata SC, Palomares F (2003) Alien mammals and the trophic position of lesser grison (Galictis cuja) in Argetinean Patagonia. Can J Zool 81:157-162

Díaz GB, Ojeda RA (2000) Libro rojo de mamíferos amenazados de la Argentina. Technical report of the Sociedad Argentina para el estudio de los Mamíferos, Argentina

Dunstone N (1993) The mink. T. and. A.D. Poyser, London
Erlinge S (1969) Food habits of the otter Lutra lutra and the mink Mustela vison Schreber in a trout water in southern Sweden. Oikos 20:1-7

Fasola L, Chehébar C, Macdonald DW, Porro G, Cassini M (2009) Do alien North American mink compete for resources with native South American river otter in Argentinean Patagonia? J Zool (Lond) 277:187-195

Ferreras P, Macdonald DW (1999) The impact of American mink Mustela vison on water birds in the upper Thames. J Appl Ecol 36:701-708

Foerster R (1973) Estudio integral sobre la presencia de visones (Mustela vison) en el Parque Nacional los Alerces y zona de influencia. Technical report, Centro de Documentación, Administración de Parques Nacionales, Argentina

Gosztonyi A, Kuba L (1996) Atlas de huesos craneales y de la cintura escapular de peces costeros patagónicos. Informe técnico $\mathrm{N}^{\circ} 4$. Technical report, Centro Nacional Patagónico (CONICET)

Harrington LA, Harrington AL, Moorhouse T, Gelling M, Bonesi L, Macdonald DW (2009a) American mink control on inland Rivers in southern England: an experimental test of a model strategy. Biol Conserv 142:839-849

Harrington LA, Harrington AL, Yamaguchi N, Thom MD, Ferreras P, Windham TR, Macdonald DW (2009b) The impact of native competitors on an alien invasive: temporal niche shifts to avoid interspecific aggression? Ecology 90:1207-1216

Ibarra JT, Fasola L, Macdonald DW, Rozzi R, Bonacic C (2009) Invasive American mink Mustela vison in wetlands of the Cape Horn Biosphere Reserve, southern Chile: what are they eating? Oryx 43:87-90

IUCN (2009) IUCN Red List of threatened species. Version 2009.1. www.iucnredlist.org. Downloaded on 13 Oct 2009

Jaksik FM, Iriarte JA, Jiménez JE, Martínez DR (2002) Invaders without frontiers: cross-border invasions of exotic mammals. Biol Invasions 4:157-173

Jêdrzejewska B, Sidorovich VE, Pikulik MM, Jêdrzejewski W (2001) Feeding habits of the otter and the American mink in Bialowieza Primeval Forest (Poland) compared to other Eurasian populations. Ecography 24:165-180

Lizarralde MS, Escobar J (2000) Mamíferos exóticos en la Tierra del Fuego. Ciencia Hoy 10:52-63

Lodge DM, Shrader-Frechette K (2003) Nonindegenous species: ecological explanation, environmental ethics and public policy. Conserv Biol 17:31-37

Macdonald DW, Harrington LA (2003) The American mink: the triumph and tragedy of adaptation out of context. N Z J Zool 30:421-441

Macdonald DW, Sidorovich VE, Maran T, Kruuk H (2002) European Mink. Mustela lutreola. Analyses for conservation. WildCRU and Darwin Initiative, Oxford

Macdonald DW, King CM, Strachan R (2007) Introduced species and the line between biodiversity conservation and naturalistic eugenics. In: Macdonald DW, Service K (eds) Key topics in conservation biology. Blackwell, Oxford, pp 186-205

Maran T, Macdonald DW, Kruuk H, Sidorovich NV, Rozhnow VV (1998) The continuing decline of the European mink Mustela lutreola: evidence for the intraguild aggression hypothesis. In: Dunstone N, Gorman ML (eds) Behaviour and ecology of riparian mammals. Cambridge University Press, Cambridge, pp 297-323

Massoia E, Chebez JC (1993) Mamíferos silvestres del Archipiélago Fueguino. LOLA, Buenos Aires

Medina G (1997) A comparison of the diet and distribution of southern river otter (Lutra provocax) and mink (Mustela vison) in southern Chile. J Zool (Lond) 242:291-297

Melero Y, Palazón S, Bonesi L, Gosálbez J (2008) Feeding habits of three sympatric mammals in NE Spain: the American mink, the spot ted genet, and the Eurasian otter. Acta Theriol 53:263-273

Melquist WE, Whitman JS, Hornocker MG (1981) Resource partitioning and co-existence of sympatric mink and river otter 
populations. In: Chapman JA, Pursley P (eds) Proceedings of the worldwide furbearers conference. Vol. 1. Donnely, Forstburg, pp $187-221$

Milano D, Ruzzante DE, Cussac VE, Machhi PJ, Ferriz RA, Barriga JP, Aigo JC, Lattuca ME, Walde SJ (2006) Latitudinal and ecological correlates of morphological variation in Galaxias platei (Pisces, Galaxiidae) in Patagonia. Biol J Linn Soc 86:69-82

Nordström M, Korpimäki E (2004) Effects of island isolation and feral mink removal on bird communities on small islands in the Baltic Sea. J Anim Ecol 73:424-433

Nordström M, Hogmander J, Laine J, Nummelin J, Laanetu N, Korpimäki E (2003) Effects of feral mink removal on seabirds, waders and passerines on small islands in the Baltic Sea. Biol Conserv 10:117-126

Nordström M, Laine J, Ahola M, Korpimäki E (2004) Reduced nest defense intensity and improved breeding success in terns as response to removal of non-native American mink. Behav Ecol Sociobiol 55:454-460

Novillo A, Ojeda RA (2008) The exotic mammals of Argentina. Biol Invasions 10:1333-1344

Oliveira GT, Fernandez FA, Bond-Buckup B, Bueno AA, Silva RSM (2003) Circadian and seasonal variations in the metabolism of carbohydrates in Aegla lingulata (Crustacea: Anomura: Aeglidae). Mem Mus Vic 60:59-62

Pagnoni G, Garrido J, Marin M (1986) Impacto económico y ambiental del visón. Mustela vison (Schreber 1877) en el norte de la Patagonia. CENPAT-CONICET, Dirección de Fauna de la Provincia de Chubut. Technical report, 20pp

Pascual M, Cussac V, Dyer B, Soto D, Vigliano P, Ortubay S, Macchi P (2007) Freshwater fishes of Patagonia in the 21st century after hundreds of years of human settlement, species introductions and environmental change. Aquat Ecosyst Health Manage 10:212-227

Pearson O (1995) Annotated key for identifying small mammal living in or near Nahuel Huapi National Park or Lanín National Park, Southern Patagonia. Mastozool Neotrop 2:99-148

Peris SJ, Sanguinetti J, Pescador M (2009) Have Patagonian waterfowl been affected by the introduction of the American mink Mustela vison? Oryx 43:648-654

Previtali A, Cassini MH, Macdonald D (1998) Habitat use and diet of mink in Argentine Patagonia. J Zool (Lond) 246:482-486

R Development Core Team (2009) R: A language and environment for statistical computing. R Foundation for Statistical Computing, Vienna, Austria. ISBN 3-900051-07-0. http://www.R-project.org

Racey GD, Euler DL (1983) Changes in mink habitat and food selection as influenced by cottage development in central Ontario. J Appl Ecol 20:387-402
Raya Rey A, Schiavini ACM (2000) Distribution, abundance and associations of seabirds in the Beagle Channel, Tierra del Fuego, Argentina. Polar Biol 23:338-345

Rodriguez-Cabal M, Amico G, Novaro A, Aizen M (2007) Population characteristics of Dromiciops gliroides (Philippi, 1893), an endemic marsupial of the temperate forest of Patagonia. Mamm Biol 73:74-76

Rozzi R, Sherrifs M (2003) The mink (Mustela vison, Schreber, Carnivora: Mustelidae) new alien mammal for Navarino Island. An Inst Patagonia (Chile) 31:97-104

Ruiz-Olmo J, Palazon S, Bueno F, Bravo C, Munilla I, Romero R (1997) Distribution, status and colonization of the American mink Mustela vison in Spain. J Wild Res 2:30-36

Schiavini A, Yorio P (1995) Distribution and abundance of seabird colonies in the Argentine sector of the Beagle Channel, Tierra del Fuego. Mar Ornithol 23:39-46

Schiavini A, Yorio P, Gandini P, Raya Rey A, Der Boersma P (2005) Los pingüinos de las costas Argentinas: Estado poblacional y conservación. Hornero 20:5-23

Schüttler E, Cárcamo J, Rozzi R (2008) Diet of American mink Mustela vison and its potential impact on the native fauna of Navarino Island, Cape Horn Biosphere Reserve, Chile. Rev Chil Hist Nat 81:599-613

Schüttler E, Klenkem R, McGeheem S, Rozzi R, Jax K (2009) Vulnerability of ground-nesting waterbirds to predation by invasive American mink in the Cape Horn Biosphere Reserve, Chile. Biol Conser 142:1450-1460

Sidorovich NE, Polozov A (2002) Partial eradication of the American mink Mustela vison as a way to maintain the declining populations of the European mink Mustela lutreola in a continental area. A case study in the Lovat River head, NE Belarus. Small Carniv Conserv 26:12-14

Sidorovich VE, Kruuk H, Macdonald DW (1999) Body size, and interactions between European and American mink (Mustela lutreola and M. vison) in eastern Europe. J Zool 248:521-527

Tatur A, Del Valle R, Bianchi MM, Outes N, Villarosa G, Niegodzisz J, Debaene G (2002) Late Pleistocen paleolakes in the Andean and Extra-Andean Patagonia at mid-latitudes of South America. Quatern Int 89:135-150

Yorio P, Frere E, Gandini P, Harris G (1998) Atlas de la distribución reproductiva de aves marinas en el litoral patagónico Argentino. Fundación Patagonia Natural, Wildlife Conservation Society, Puerto Madryn, p 221

Zar JH (1984) Biostatistical analysis. Prentice-Hall International, Upper Saddle River 